\title{
The Srebrenica exhibition
}

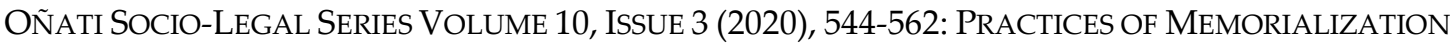 \\ AND THE PROCESS OF SOCIAL RECONSTRUCTION \\ DOI LINK: HTTPS://DOI.ORG/10.35295/OSLS.IISL/0000-0000-0000-1110 \\ RECEIVED 29 NOVEMBER 2018, ACCEPTED 07 NOVEMBER 2019
}

\section{DION VAN DEN BERG* \\ MARTIN J.M. HOONDERT*}

\section{Abstract}

In February 2017, an exhibition was opened in Srebrenica (Bosnia and Herzegovina) telling the story of the Bosnian war (1992-1995) and the Srebrenica genocide (1995). In this article we describe how the exhibition was designed and we reflect on the impact of the exhibition on the processes of restorative justice and social reconstruction. Leading question is: Does the exhibition successfully construct a shared sense of truth about the Srebrenica genocide? This evaluative question demands insight in the concept of truth and, more specific, in the debate about plural truths and multiple narratives.

\section{Key words}

Srebrenica; genocide; exhibition; truth; restorative justice

\section{Resumen}

En febrero de 2017, se inauguró en Srebrenica (Bosnia-Herzegovina) una exposición que narraba la historia de la Guerra de Bosnia (1992-1995) y el genocidio de Srebrenica (1995). En este artículo, describimos cómo se diseñó la exposición, y

\footnotetext{
* Dion van den Berg (1960) is head of the Europe team of peace organization PAX, based in the Netherlands. He started working for PAX (then still IKV) in 1980. His involvement in Yugoslavia and Bosnia and Herzegovina started in 1987. Ever since 1995, he worked Srebrenica and the consequences of the genocide. Contact details: PAX, PO Box 19318, NL - 3501 DH Utrecht, Netherlands. Email address: vandenberg@paxforpeace.nl

* Martin J.M. Hoondert (1967) is associate professor of Ritual Studies at Tilburg University (the Netherlands). His research focuses on "music and death" and "practices of memorialization". His research topics are: the contemporary Requiem, musical repertories of funeral rites, commemoration and music, music and grief, music and the First and Second World War, practices of memorialization regarding genocide (esp. Rwanda and Srebrenica). In cooperation with the universities of Cardiff (UK), Leuven (Belgium) and San Sebastian (Spain) he has established a network focusing on research into practices of memorialization and the process of social reconstruction after atrocities (see www.pracmem.eu). Contact details: Tilburg University, PO Box 90153, 5000 LE Tilburg, Netherlands; email address: m.j.m.hoondert@tilburguniversity.edu
} 
reflexionamos sobre el impacto de la exposición en los procesos de justicia restaurativa y reconstrucción social. La pregunta que nos guía es: ¿Consigue la exposición construir un sentido compartido de verdad sobre el genocidio de Srebrenica? Esta pregunta evaluativa exige indagar en el concepto de verdad y, más específicamente, en el debate sobre pluralidad de verdades y multiplicidad de narrativas.

\section{Palabras clave}

Srebrenica; genocidio; exposición; verdad; justicia restaurativa 


\section{Table of contents}

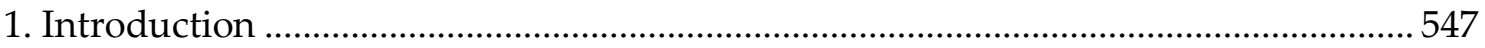

2. The Srebrenica genocide and the involvement of Dutchbat ........................................549

3. Commemorative rituals related to the Srebrenica genocide...................................... 550

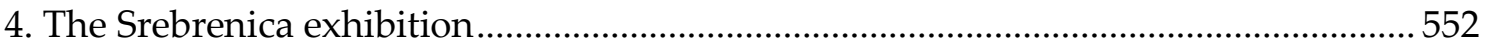

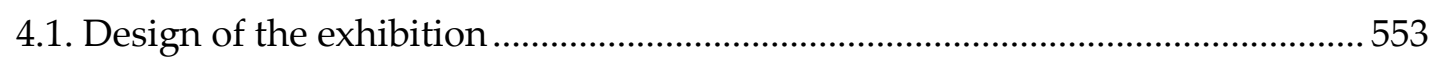

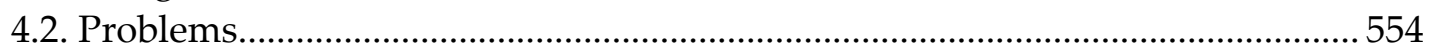

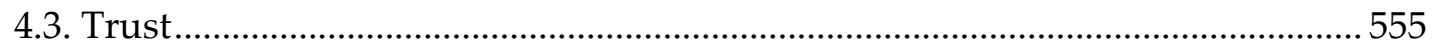

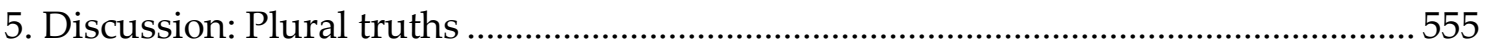

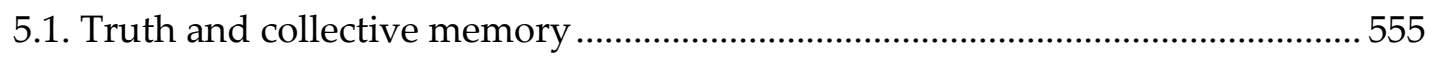

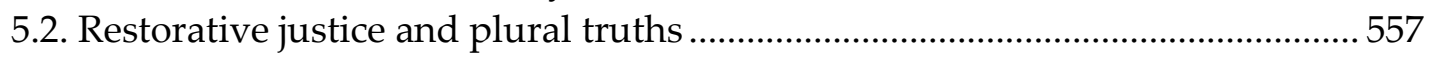

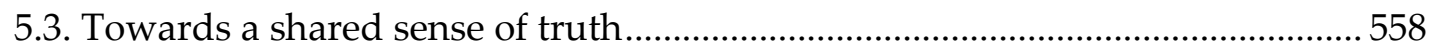

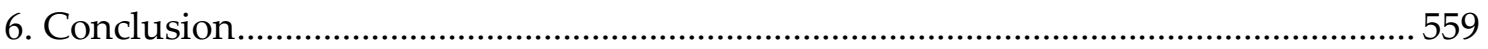

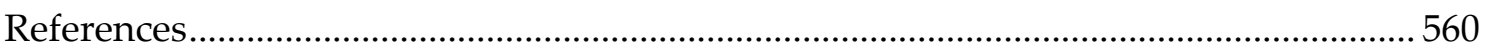

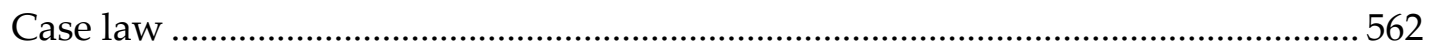




\section{Introduction}

On 11 July 1995, the UN safe area Srebrenica, a Bosniak enclave in Eastern Bosnia, with 40,000 people hoping for survival, fell into the hands of the Bosnian Serb Army, led by general Ratko Mladić. After the fall of the enclave, an estimated 15,000 men tried to escape through the woods, while over 25,000 women, children, elderly people and a group of about 1,880 men (International Committee of the Red Cross 1997) sought safety in and around the main compound of the Dutch UN peace-keepers (Dutchbat) in Potočari. From these 25,000 Bosniaks (as the Bosnian Muslims are called), the women, children and elderly were deported to the territory under the control of the Bosnian Army. Men were separated from the others, and all of them were killed. From the 15,000 men trying to flee through the woods, thousands were captured and killed. In total, according to the official list 8,372 Muslim men and boys were killed, either in the woods or after being captured and transported to execution sites (Blom and Romijn 2002).

The fall of Srebrenica is one of the rock bottoms in the Bosnian War (1992-1995). The focus of this article, however, is not on the occurrences in the Bosnian War, but on postwar practices of memorialization regarding Srebrenica in relation to restorative justice and social reconstruction. In the next section, we will give some necessary background information regarding the situation in Srebrenica during the Bosnian War and the involvement of Dutch UN-peacekeepers. We will not go into the long history of violence, war and ethnic cleansing in the region and confine us with regard to these issues to referring to some relevant studies that deal with developments in the $20^{\text {th }}$ century (Perica 2002, Gallagher 2003, Bergholz 2018).

In 2003 a memorial centre was opened at Potočari, the neighbouring village of Srebrenica. This Potočari Memorial Centre (PMC; see www.potocarimc.org/) is located at the former Dutchbat compound, a former battery factory. ${ }^{1}$ At the other side of the road, the victims of the Srebrenica genocide are buried. At this moment, 6,610 victims have been buried; the remains of the other more than 1,700 victims have not been found yet or wait for identification. Every year, at 11 July, various commemoration practices take place here, attracting both Bosniaks from the whole of Bosnia and Herzegovina and a lot of international public (sympathizers and delegates of governments, NGOs and international organisations) (Hoondert 2018).

In 2014, after more than five years of preparation, the Dutch peace organization PAX presented a project proposal for the foundation of an exhibition or memorial museum in the PMC. Ever since 1995, PAX has been working on Srebrenica. PAX supported the lobby for the cemetery and the memorial centre from the very beginning and facilitated in co-operation with others various meetings between Dutchbat veterans and the Srebrenica survivors (PAX 2017). In the project proposal, dated April 2014, the aim of the project is described as follows:

The main aim of the program is to give a coordinated 'Dutch contribution' to the development of the Potočari Memorial Centre, as a center that will tell the story of

\footnotetext{
${ }^{1}$ The Srebrenica-Potočari Memorial and Cemetery for the Victims of the 1995 Genocide, in short PMC, now an institution of the State of Bosnia and Herzegovina, was established by the Decision of the Office of the High Representative (OHR) of 25 June 2007. It is composed of two components: the memorial part at the former Dutchbat compound, and the cemetery. It was first established by OHR as an international foundation, in May 2001.
} 
Srebrenica during the war (making use of multiple narratives) and that will extend a strong message to the world: 'Srebrenica should never happen again!' A multi-faceted exhibition will picture the development of the Srebrenica - Netherlands relations since 1995. (PAX 2014, p. 4)

The idea of an exhibition, telling the story of the siege and fall of the enclave of Srebrenica, the deportation of the children, women and elderly persons, the flight of the men and boys, the genocide and the role of both Dutchbat and the international community, had been raised in the years before. The initial request for such an exhibition had been voiced by the survivors of the genocide, and PAX had started a series of informal consultations to test the waters for this idea. An important step was made in December 2012, when the chairperson of the PMC, Mr. Sadik Ahmetović, and the PMC director, Mr. Mersed Smajlović, visited the Netherlands, upon invitation of PAX. They met with, among others, Dutchbat veterans, employees of Camp Westerbork (a so-called "Durchgangslager" in the Netherlands, during the Second World War; now a memorial museum and as such an expert in designing memorial exhibitions), Members of Parliament and representatives of the Dutch Government. During that visit the idea of an exhibition was presented and discussed. The Dutchbat veterans offered assistance in the reconstruction process. The Defense Ministry emphasized its hope that the role of the Dutch would be presented in a professional and objective way (PAX 2014, pp. 5-6).

In this article we will describe the creation of the exhibition and evaluate its impact. The first aim of our article is to describe the process of designing an exhibition in a postconflict situation, which is, unfortunately, still very tense and complex. The second aim of our article is to evaluate the resulting exhibition with one leading question in mind: Does the exhibition successfully construct a shared sense of truth about the Srebrenica genocide? This evaluative question demands insight in the concept of truth and, more specific, in the debate about plural truths and multiple narratives. Both the description of the design of an exhibition in a post-conflict though tense situation and the discussion regarding the impact of the exhibition can lead to insights that go beyond the boundaries of the case study which is central to this article. Worldwide, survivors of war crimes and organizations supporting them are working on museums and exhibitions, and concepts of truth and multiple narratives are discussed at many places (see www.sitesofconscience.org/en/home/).

This article is the result of cooperation between a scholar and a practitioner. Hoondert is the scholar, trained in ritual studies, memory studies and culture studies in general; Van den Berg is the practitioner, employee of the Dutch peace organization PAX. Van den Berg was, and still is, highly involved in the relationship between the Netherlands and organizations in and related to Srebrenica. From the very start, he was involved in the creation and design of the exhibition and he wrote, together with others, the texts which are shown on the panes, telling the history of the Bosnian war and explaining what is shown on the many photos that are exhibited. In writing this article, we discussed the complexity of the Srebrenica case, partly disagreed on how to evaluate the resulting exhibition, but learned from each other. Van den Berg took the lead in the description of the creation and design of the exhibition, Hoondert in the evaluation. We both take responsibility for the entire article. 


\section{The Srebrenica genocide and the involvement of Dutchbat}

In the process of disintegration of Yugoslavia, the war in Bosnia and Herzegovina (19921995) was the bloodiest one, with the genocide of Srebrenica as the cumulation of violence and ethnic hatred (Attila Hoare 2010, van den Berg 2014, Spijkers 2016). March 1992, a majority of the citizens of Bosnia and Herzegovina had voted in a plebiscite for an independent state. Bosnian Serb politicians did not accept that decision, and their political leader Radovan Karadžić warned independence would "take Bosnia and Herzegovina to hell and the Muslim nation possibly to its disappearance". Spring 1992, ethnic cleansing started - in particular in eastern Bosnia. The towns of Srebrenica, Žepa and Goražde became three big Bosniak enclaves in that part of the country. Spring 1993, the UN declared six cities and regions "UN safe areas", Srebrenica being one of them. Canadian soldiers (CANBAT) did the first shift, and the Dutch took over in February 1994.

July 1995, the Bosnian Serb Army (BSA) launched its attack on Srebrenica. Dutchbat commander Karremans had sent alarming reports through the UN chain of command in the days prior to the attack, but to no avail. In their advancement, the Bosnian Serbs targeted the Dutchbat Observation Posts (OPs), and the Dutchbat crews abandoned them. The UN report on Srebrenica (1999) stated that Dutchbat did not fire a single round of bullets at the Serbian forces. Dutchbat requests for air support were not granted or called off, at one occasion also by the Dutchbat commander himself. July 11, the Bosnian Serb Army entered the town of Srebrenica. Dutchbat concentrated its troops at the compound in Potočari, allowing 5,000 to 6,000 people onto the compound as well, in a big hall. Another 20,000 were not allowed in, and stayed in the vicinity of the compound. In the night of 11 to 12 July, a group of 15,000 men started an attempt to escape through the woods. July 12, the Bosnian Serbs showed up in Potočari. Once BSA general Mladić found out that a large group of men was trying to escape, he ordered his troops to attack the columns. Mladic bullied and humiliated Dutchbat commander Karremans at three meetings, the evening of July 11 and morning of July 12. Unexpectedly, the Bosnian Serbs initiated the deportation from Potočari, separating the men from the women and children. The women, children and elderly were taken to the frontline near Kladanj and sent by foot into territory under the control of the Army of Bosnia and Herzegovina. That first day of the deportation, July 12, Dutchbat members saw dead bodies and witnessed at least one execution in the vicinity of the compound. Trying to prevent brutal actions, Dutchbat had assisted in the deportation. Despite of the information about what was happening to the men, Dutchbat didn't stop its assistance for the deportation. In the afternoon of July 13, Dutchbat ordered all people at the compound (mostly women and children, but also an estimated 300 men) to leave the compound. A few hours later, all Bosniaks were gone. All men who had looked for safety in Potočari would be killed. A few days later, Dutchbat left Srebrenica. A party in Zagreb, with music and beer, was not well received by many. By then, it was clear that many men were not accounted for and fear for mass atrocities and genocide had been voices already. 
Critical questions surfaced very soon, thanks to investigative journalism and civil society organizations. ${ }^{2}$ Pressured by the public opinion and parliamentarians, the Dutch government commissioned a report on Srebrenica, the so-called NIOD report. Following that report, the government of prime minister Wim Kok resigned, in April 2002, referring to "the political co-responsibility for the failure of the international community". His and later governments did not accept responsibility for mistakes made by Dutchbat in the field. More than once, politicians spoke of "rehabilitation" of Dutchbat. Yet, civil law suits initiated by survivors and next of kin against the state of the Netherlands have led to important rulings by the Supreme Court of the Netherlands, holding the Netherlands government responsible for initially the death of three men, UN electrician Rizo Mustafic and the father and brother of UN interpreter Hasan Nuhanovic, and in a later ruling the death of 300 men. ${ }^{3}$ The discussion in the Netherlands on Srebrenica is ongoing.

To understand the complexity of post-conflict Bosnia and Herzegovina, we will start by describing some rituals which are performed every year in July to commemorate the Bosnian war and the Srebrenica genocide. This description is meant as part of the contextual background, revealing the tensions, the narratives and counter-narratives, or - to use some words that sound a bit more peaceful: the polyphony of truths.

\section{Commemorative rituals related to the Srebrenica genocide}

The Srebrenica case is characterized by a complexity of commemorative rituals. Focusing on the main ritual on 11 July at the Potočari Memorial Centre and the impressive cemetery where the victims of the Srebrenica genocide are buried, we see several adjacent and counter rituals. We will confine the description to three commemorative rituals, leaving out, for example, the impressive Mars Mira (Peace March, see Nettelfield and Wagner 2015, pp. 52-61). The description of the first ritual is based on literature and online sources. The description of the second and third ones are based on our site visit in July 2015. This was a special occasion due to the $20^{\text {th }}$ commemoration of the genocide.

On the eve of the commemoration and burial service in Potočari, on 10 July, a group of women and other citizens gathers in downtown Belgrade, the capital of Serbia. ${ }^{4}$ This group is led by the so-called Women in Black, an NGO formed in 1991, just after the former Yugoslavia began to disintegrate and the war broke out. During the war, the Women in Black were already standing in weekly vigils at the Republic Square in Belgrade, protesting against the war, the killing of innocent people, and against silencing of the perpetration of war crimes. In the aftermath of the war, the group continued to remind the citizens of their country of Serbia's atrocious past. The yearly gathering on 10 July has become part of a "war of memories". While the Women in Black and other

\footnotetext{
2 The government did not engage in any serious discussion on Srebrenica, as - so they said - this would interfere with the independent research done by the Netherlands Institute on War Documentation (NIOD). Disturbing information continued to surface, and a comprehensive critical analysis was published a few weeks before the presentation of the NIOD report by peace organization IKV (Faber 2002).

${ }^{3}$ See respectively for the ruling of 6 September 2013 (ECLI:NL:HR:2013:BZ9225) and for the ruling of 19 July 2019 (ECLI:NL:HR:2019:1223). In the latter ruling, the court states that the Dutchbat performance was unlawful, but the state is only to pay for $10 \%$ compensation, as according to the court the men would have had a chance of only $10 \%$ to survive if Dutchbat would have acted otherwise.

${ }^{4}$ In 2018, the Women in Black gathered on the 11th of July; see Bellamy 2018.
} 
Belgrade-based NGO's commemorate Srebrenica as genocide, others protest against this event, celebrating the $11^{\text {th }}$ of July as the "Liberation of Srebrenica".

The commemoration on 11 July in Srebrenica-Potočari consists of two parts. The first part is only accessible for representatives of governments, other officials and invited guests. The second part is the burial and commemoration of the victims of the Srebrenica genocide. In 2015, the commemoration started at the Memorial Centre with speeches by, among others, the Mayor of Srebrenica, former US President Bill Clinton and the Dutch Minister of Foreign Affairs Bert Koenders. After the speeches by the officials, the invited guests all left the Memorial Centre and walked to the cemetery. There, 136 coffins with the remains of the victims of the Srebrenica genocide, recently identified using DNA analysis, were waiting to be buried. The mass burial of the 136 victims was an impressive and worthy ceremonial. Ten thousand Muslim men and women took part in the funeral prayers before the coffins were carried to the graves. In the meantime, the names of the victims were read by a woman as a litany for the dead. Each coffin was accompanied by an imam, who said the required prayers at the graveside. While the ceremony had started as a collective Muslim ritual, the ritual changed into 136 individual family rituals (see also Pollack 2003).

Although the 11 July commemoration in Srebrenica-Potočari gets the most attention in the international media, it is not the only ritual in this part of Bosnia and Herzegovina related to the Bosnian War. Every year, the day after the commemoration and burial service in Potočari, a memorial service and wreath-laying ceremony takes place in the village of Zalužje (also: Zalažje; municipality Bratunac), near Srebrenica. ${ }^{5}$ On 12 July, the Serbs commemorate the massacre of Serb civilians and soldiers they claim were killed by Bosnian Muslim forces under command of Naser Orić on 12 July 1992. This commemoration, and the many others in the villages of Republika Srpska, get hardly any attention in the international media (with the exception of media in Serbia). The ceremony takes place at the memorial in Zalužje and is led by Orthodox Serb priests. According to Serb sources, 69 Serbs were killed and 22 were taken prisoner. All prisoners were tortured and eventually murdered in Srebrenica camps. ${ }^{6}$ The memorial consists of two mausoleums and a wall with the names and pictures of the victims of the 1992 attack.

These three rituals are different ways of dealing with the troubled past of Srebrenica. The narratives of the past differ and there is no shared truth, no time and space where the polyphony of opposite narratives can be heard. Moreover, the rituals are loaded with opposite interests. The presence of the Women in Black in Belgrade is an attempt to restructure the narrative of Srebrenica in the minds of the Serbs, and to offer a counternarrative against the genocide denial, the relativism of numbers of victims and the glorification of war criminals who participated in the genocide of Srebrenica. The commemoration in Zalužje is an attempt to counter the dominant narrative in the international media which, according to the Serbs, tends to narrow the consequences of

\footnotetext{
${ }^{5}$ We did not visit this ritual ourselves, but were informed about it by one of the members of the delegation with which we visited Srebrenica in 2015. Hoondert interviewed this member, a former Dutchbat soldier, on the day of the Zalužje ritual and received the pictures he took during the ritual.

${ }^{6}$ See N1 Sarajevo 2018. In the ICTY records regarding Orić, Zalužje is not mentioned (see ICTY n.d.) Orić was acquitted by the ICTY (see ICTY 2008), even though the ICTY concludes that grave crimes were committed against the Serbs in the region of Srebrenica. Other members of the Potočari Territorial Defence, led by Orić, were sentenced for crimes committed in Zalužje (see Grebo 2018).
} 
the Bosnian War to what happened in Srebrenica and the Bosniaks' sufferings. For the survivors and the next-of-kin of the Srebrenica genocide, the first aim of the official commemoration is to bury the recently identified victims and to pay respect to the dead. Besides these aims, the commemoration and burial on 11 July for many Bosniaks also serve political purposes. First, to save up the remnants of the identified dead to bury them collectively once per year shows the extent of the 1995 genocide in a convincing way. The imaginative power of this "guilty landscape" (Alphen 1997, p. 128, Reijnders 2013) is used to convince, in particular, the international community of the atrocities committed by the Bosnian Serbs. Second, the burial ritual and commemoration are also a "ritual of confrontation" (Brosius 2007, p. 297): the international community is confronted with its failure and even guilt. In addition, as the guides of the PMC explain and the speeches and the prayer on 11 July clearly show, the PMC extends an obligation to the world to never allow another genocide to happen. Third, the burial ritual and commemoration confronts the Bosnian Serbs with their past. The permanent presence of the cemetery with its Muslim grave pillars on the hill just at the border of Potočari confronts the Bosnian Serbs with the crimes they have committed. Fourth, the cemetery and the presence of so many dead bodies of killed Bosniaks is a way of reclaiming the land and in doing so claiming the right to exist in this part of Bosnia and Herzegovina. The cemetery and the yearly commemoration not only refer to the past, but also claim a place in the present.

\section{The Srebrenica exhibition}

Ever since the PMC was set up, survivors had voiced suggestions for a big museum in the former Dutchbat compound to complement the already existing educational components of the so-called "Spomen Soba" (memorial room) and the Black Box that shows a short video on the genocide of Srebrenica. But it would take a few years before the suggestions crystallized into a more concrete idea and a request presented to PAX. ${ }^{7}$ It was clear from the outset that making such an exhibition would be quite a challenge, also because, already in an early phase, discussions started on incorporating Dutchbat stories next to the stories of the survivors.

A series of informal consultations followed, with Camp Westerbork, individual Dutchbat veterans and the Netherlands Embassy in Sarajevo, but first and foremost with the steering board and staff of the PMC and the associations of survivors. ${ }^{8}$ Upon request of the Embassy, also formal consultations were held with the Foreign Ministry and the Defense Ministry in The Hague. Both Ministries and the Embassy were quite clear in their position that they appreciated moments of consultation but that PAX had the full mandate to make decisions on the content, having in mind the principles as defined in the project application.

Upon the basis of the project application, finalized in April 2014 and presented by PMC, Camp Westerbork and PAX as lead agency, the Embassy had decided to grant a

\footnotetext{
${ }^{7}$ In these first years, the key challenge had been to agree on the design for the cemetery and to work on the facilities at that "sacral part" of the PMC.

8 There are four main associations of survivors of Srebrenica, and relations between the associations are at times very bad. They all have a representative in the Advisory Committee of the PMC, and they can easily block proposals in their advisory role. In the end, all associations supported the idea and design of the exhibition.
} 
donation for the whole project, divided over two contracts (one with PMC and one with PAX). The over-all project consisted of five key components: the reconstruction of the building; activities related to OP Foxtrot, one of the Dutchbat observation posts in the mountains; reconstruction of one of the watchtowers at the compound; capacitybuilding activities for PMC and associations; and the exhibition. PMC had the lead for the reconstruction of the former Dutchbat Headquarters, PAX for the other components. The design and lay-out for the exhibition were commissioned by PAX to Camp Westerbork. The writing of the text would be the joint endeavor of the curator hired by Camp Westerbork, and two persons representing PMC and PAX. ${ }^{9}$

The project application listed various principles, among them to preserve the authenticity of the building and the need to work upon the basis of professional international standards. Also the concept of "multiple narratives" was mentioned, but with an important reflection attached:

We know that approaches to certain elements of narratives will develop over time; as a rule, distance in time offers more opportunities to accept multiple narratives. It is nevertheless to be understood that the speed of that process will be largely determined by the willingness and capacities of the main owners of the PMC: the survivors of the Srebrenica genocide. (PAX 2014, p. 9)

\subsection{Design of the exhibition}

The title selected for the exhibition, after long discussions, was The Srebrenica Genocide. The Failure of the International Community. Camp Westerbork developed a design that incorporated four layers or story lines, covering all 26 rooms and spaces of the former Dutchbat compound. The chronological story line begins in 1992 and ends in Fall 2016, thus including the work of the associations of Srebrenica, but also the initiatives of Dutchbat veterans and the ruling in Dutch court rooms in civil law suits initiated by the survivors against the state of the Netherlands. The functional story line provides extra information on the role and function of that particular room back in 1994 and 1995. Information on Dutchbat commander Karremans and his actions in July 1995 can be found in the little room that used to be his office, information on connections with the outside world is given in the Communication Room. The personal story line tells the story of one genocide victim, the young boy called Riki Fejzic, son of one of the leading activists of one of the associations. A fourth, special dimension is incorporated by means of the documentaries under the title Various Voices, in which personal statements of sixteen survivors and nine Dutchbat veterans are clustered around some of the most contested topics and moments, such as the separation of men and women, and the party in Zagreb. ${ }^{10}$

A monument in itself is the foil that covers the top meter of all windows. The names of all victims of the genocide are printed on the foil, in alphabetical order.

\footnotetext{
${ }^{9}$ Respectively Monique Brinks, Hasan Nuhanovic and Dion van den Berg.

10 Organised for Dutchbat personnel by the Netherlands Army, 23 July 1995, upon their safe arrival in Zagreb. Dutchbat soldiers drank beer and danced the polonaise, while the killing of Bosniaks was still taking place in Eastern Bosnia.
} 


\subsection{Problems}

In the process of implementation, various problems were encountered. And even some of the anticipated issues grew bigger, for a variety of reasons. In the period of consultation, PAX and Camp Westerbork had had various moments of consultation with Dutchbat veterans, asking for their individual contribution to the project. It had been a deliberate choice not to ask for the formal approval or commitment of the two existing groups of Dutchbat veterans. Yet in the course of the implementation of the project, the Working Group Dutchbat III was established by the Dutchbat veterans in order to lobby with the Dutch government for recognition of their sufferings in relation to their mission in Srebrenica and apologies for the inadequate mandate regarding Dutchbat's mission. The Defense Ministry clearly indicated that the government attached great value in good cooperation with that new Dutchbat initiative, and asked PAX and Camp Westerbork to consult with the Working Group. At a certain point, members of the Working Group considered asking the government to stop all cooperation with PAX and Camp Westerbork, and suggested it could ask all individual veterans to withdraw their permission to use photos and footage. In the end, that luckily didn't happen.

In the same period, tensions between the active members of the Srebrenica survivors' associations and many in the Dutchbat community rose because of ruling of various Dutch courts. Disagreement on certain issues became very visible. Things got worse when a number of graffiti were destroyed with the reconstruction of the former Dutchbat Headquarters. Most of the graffiti were drafted by Dutchbat soldiers during their stay at the compound (1994-1995). Dutchbat veterans claimed that the graffiti was probably deliberately destroyed to make the innocent graffiti disappear and put the most contested graffiti, the sexist and racist ones, even more in the spotlight. Yet for PAX it was clear that lack of clear instructions and surveillance over the reconstruction works was the cause. ${ }^{11}$

At times, these unexpected developments also had an impact on the cooperation between PAX and Camp Westerbork, with PAX communicating most extensively with the survivors and Camp Westerbork being in charge of the consultation with the Dutchbat veterans.

The last months before the opening of the exhibition, the three persons working on the text (representing PMC, Camp Westerbork and PAX) had spent numerous long skype calls on discussing various drafts for the texts and the captions explaining the photos, maps etc. By that time, the planning for the opening had been postponed already twice, and still it was a race against the clock.

The day before the official opening first the survivors and then the Dutchbat veterans had their private pre-view of the exhibition. Logically, all of them were present at the official opening the day after, but it was useful to give them an opportunity to see the exhibition earlier and voice a first reaction. Both the women of Srebrenica and the veterans were positive. At the day of the official opening of the exhibition, the media in Bosnia, with the exception of the Bosnian Serbian media, were very positive about the exhibition. Many of the survivors gave positive statements. The Dutch media had chosen

\footnotetext{
${ }^{11}$ It was very painful though, also because PAX and Camp Westerbork had been offering assistance in professional preservation of the graffiti for some twelve years.
} 
to focus more on the controversy over the graffiti and the fact that Bosnian Serb inhabitants don't like the PMC altogether and that some local Bosniaks prefer economic development over transitional justice initiatives.

\subsection{Trust}

Looking at this challenging project objectively, it was quite an achievement. One of the people involved called it "a little miracle". Despite of the problems and disagreements, there may have been two main reasons why it was possible to finalize the exhibition. Firstly, after a long and careful consultative process, the three writers - after more than a month of almost daily skype meetings - managed to agree on the texts. Secondly, there was sufficient trust. The survivors trusted Hasan Nuhanovic, their representative in the writers' group, to present their needs and wishes, the key issues but also the details; they also trusted PAX, the organization that supported their campaign for truth and justice ever since 1995. They also saw that the design elaborated by Camp Westerbork was powerful. Many of the Dutchbat veterans worked with Camp Westerbork through the "guest speakers" project for secondary schools. They trusted Camp Westerbork, also because that organization had initiated a first veterans' group visit back to Srebrenica, in the year 2007. PAX had joined the organization of that visit, and co-organized various follow-up activities. Even though discussions among the stakeholders were manifold and indeed caused delay more than once, the fact that the organizations had a history with each other and with the survivors and Dutchbat veterans, that they had built a basis of trust, helped to make the project a success - in the eyes of both the survivors and the veterans (Remijnse and Baanders 2018).

\section{Discussion: Plural truths}

There are many ways to evaluate the Srebrenica exhibition. The success can be measured on the basis of numbers of visitors, or visitors' responses to the exhibition. ${ }^{12}$ The comprehensive content of the exhibition is unique for Bosnia and Herzegovina in which narratives about the past are mostly framed by ethnic and/or religious affiliation. For our evaluation we have chosen to focus on the content and design of the exhibition and to discuss the question: Does the exhibition successfully construct a shared sense of truth about the Srebrenica genocide? This question is directly linked to the (ritual) tensions, described in the third section of this article.

\subsection{Truth and collective memory}

The question regarding a shared sense of truth seems to be an unanswerable question. How to conceptualize "truth" in the complex web of disperse personal and collective memories? Truth seems to be very relative, i.e. related to ethnic backgrounds and political purposes. Related to "truth" is the concept of collective memory, i.e. the narrative of (a specific part of) the past as told by a specific group. This collective memory might be unstructured. containing loose ends and unclear points. Bringing the

\footnotetext{
12 Based on research performed in April 2019, we can conclude that the number of visitors is high. Each day, several groups and individuals visit the PMC. The majority are from Bosnia Herzegovina, the second largest group are Italians; the third largest group are Dutch people. In our research we asked visitors to evaluate the exhibition with a grade between 1 and 10 with 1 as "very bad" and 10 as "very good". Overall the exhibition was received very positively, on average the exhibition has been graded with an 8.9.
} 
collective memories of several groups together in one exhibition is a way of institutionalizing memories. The process of institutionalizing evokes a need for political decision-making (Meyer 2010), for such a project can't do without taking current interests into account, especially in the ethnically pluralistic society of Bosnia and Herzegovina. That is what we concluded in the analysis of the commemorative practices related to Srebrenica and the Bosnian war, the same is true for the exhibition. So, we do not raise the question regarding a shared sense of truth in order to evaluate if the image of history presented in the exhibition is scientifically comprehensive and truthful, but to evaluate how that image is linked to political purposes and how - if at all - it contributes to the transitional justice agenda (Simic 2017).

Srebrenica as a site of memory (Nora 2001, Winter 2010) evokes different narratives, told from different perspectives. This is also the case in the exhibition. On the one hand, there is the more or less "official account" of the facts as derived from internationally recognized sources, such as the UN report regarding Srebrenica of 1999 and verdicts by the International Criminal Tribunal for the former Yugoslavia (ICTY). In the exhibition, in particular these reliable sources have been used as sources. This deliberate choice is in itself both remarkable and important, given the fact that this international standard is only upheld in a few exhibitions and museum in the former Yugoslavia (see, for example, MacDonald 2003). On the other hand, there are the personal stories as shown in the documentaries based on interviews with representatives of the diverse involved parties (survivors, Dutchbat soldiers; the voice of the Bosnian Serbs is not part of the exhibition), deliberately referred to in neutral terms as "various voices".13 In these interviews we hear opposite views on what happened during the siege and fall of Srebrenica - albeit not from all three perspectives, but nevertheless two often conflicting perspectives.

Peace organisation PAX that developed the exhibition project and commissioned preparation of the design to Camp Westerbork, has promoted the concept of "various voices" and "multiple narratives" as a way of dealing with the past and as a way to explore to which extent the owners of the PMC, the Bosniak survivors, could support incorporating Dutchbat experiences and narratives in the exhibition. Odile Heynders, professor in literature at Tilburg University, the Netherlands, elaborated on the concept of multiple narratives from the perspective of life writing. Life narrative or life writing is the umbrella term for stories representing a life or part of life, in this case, the stories of Srebrenica during the Bosnian war. These stories are always interwoven with other stories: "storytellers are part of a shared context of meanings that they do not (only) create themselves. Because of the relatedness of stories, it is difficult to decide upon the truth of any one story, since no speaker has the final representation at their disposal of all the perspectives and historical and political facts" (Heynders 2014, p. 5). Comprehensive truth in the Srebrenica case only exists in the multiplicity of narratives and in the exhibition three narrative contexts have been brought together: the official, more or less factual account, the personal experiences of the survivors and the personal

\footnotetext{
13 See the teaser of this documentary on YouTube: https://www.youtube.com/watch?v=Ur1rGOWQxIQ (accessed 22 November 2018). The total time of the documentary as shown in the exhibition is more than two hours (133 minutes).
} 
experiences of the Dutchbat soldiers. It is in the combination of these narrative contexts and the plurality of truths that - paradoxically - a shared sense of truth might occur.

\subsection{Restorative justice and plural truths}

To bring the issue of plural truths in relation to a shared sense of truth a bit further, we can find inspiration in the field of transitional justice (Simic 2017). Scholars and practitioners working in this field added concepts of retributive justice to the classical restorative justice (e.g. Nils 2005), although we have to admit that in real terms most of the attention and money still goes to projects which focus on rule of law and criminal justice. From a focus on accountability for crimes and criminal prosecutions of perpetrators, scholars and practitioners following the restorative justice approach have come to a broader response to atrocities, which is summarized by among others Stephan Parmentier in a model (the so-called "TARR-III model") which is in essence a dialogical process (Jones et al. 2014). This dialogical process is clearly visible in the view on both crime and truth. Crime is approached from the perspective of personalism as "a violation of people and their relationships rather than a violation of law." (Jones et al. 2014, footnote 2). Truth is conceptualized as restorative truth, "meaning the truth that places facts and their meaning within the context of human relationships." (Jones et al. 2014, p. 152) Farida Shaheed, the UN Special Rapporteur in the field of cultural rights, elaborated on the concept of "dialogical truth" in her report for the Human Rights Council in 2014:

... what counts is creating conditions that allow a 'broadly located, mobile, multilayered and interactive dialogical truth' to emerge, meaning a debate on past events and actions that enables society to overcome 'completely separate and unrecognized accounts of what happened' so as to move forward and develop more peaceful relationships. (...)The central issue is how to ensure that people hear the story of others and learn to recognize their common humanity. (Shaheed 2014, $\left.\mathrm{n}^{\mathrm{o}} 20\right)^{14}$

On the one hand, this is partly accomplished in the exhibition through the "various voices" that invite the visitors (also those directly involved in the Srebrenica case: the survivors and the Dutchbat veterans) to engage with the plurality of truths. On the other hand, we are very much aware that the restorative justice approach does not (or: not yet) fit the situation in Bosnia and Herzegovina, where group identity (related to either ethnicity or religion) and thus criminal justice and accountability seem to be key (Humphrey 2012). That is among other clearly visible in the fact that court rulings, whether from the ICTY or domestic courts, are not assessed upon the basis of the facts established in the court room or their legal righteousness, but solely on the ethnic background of perpetrators and victims.

Yet, PAX tries to incorporate elements of the restorative justice approach in its Theory of Change on Dealing with the Past, which states that transitional justice processes should be "as inclusive as possible". This also relates to commemorative practices. The inclusivity is the ideal, but the complexities of reality and the contextual possibilities and limitations are taken into account by stating that practices are as inclusive as possible.

Although the restorative justice approach touching upon dealing with the past as a joined effort and as an effort of dialogue and shared truth, is rather idealistic, it may

${ }^{14}$ Shaheed cites Albie Sachs in this quote; see Sachs 2000. 
provide us with suggestions how to develop the exhibition, and more broad the work of the PMC, in the coming years. The exhibition as such is not an end point, but just one step - and an important one - in an ongoing process of social reconstruction, i.e. a process that ultimately aims at bringing about a situation in which victims, perpetrators and witnesses peacefully co-exist. Even now political developments in Bosnia and Herzegovina are rather deteriorating, it is worthwhile to continue working on such longterm strategies. Social reconstruction of Bosnia and Herzegovina is a complicated process and demands "negotiations" in a way to reach agreement on a base line truth that all parties involved agree on or find acceptable. To reach agreement on truth and a shared narrative about the atrocious past is part of the process of social reconstruction, which is, in the end, a situation of social cohesion, tolerance and peaceful co-existence. The exhibition is an important step in this process of social reconstruction, for a museum or exhibition is perceived to speak with an authoritative voice. However, there is always the risk that an exhibition may be used to promote political agendas or to defend community interests through the presentation of a particular narrative (Shaheed 2014, $n^{-}$75). Selective appropriations of an exhibition as an authoritative voice can't be controlled by the designers of the exhibition. Could this be the case for (part of) the Dutch political elite and individual Dutchbat soldiers? Although the exhibition is very critical about the role of the Dutch government and Dutchbat regarding the fall of Srebrenica (made visible in the exhibition through the information about the interventions and noninterventions from the Dutch government in The Hague, the decisions made by commander Karremans etc.), the focus on the "failure of the international community" might guide away from the specific responsibility at the Dutch side for the fall of the enclave of Srebrenica.

\subsection{Towards a shared sense of truth}

As said, inspired by the dynamics of restorative justice and the principle to promote inclusivity where possible, we will mention two issues which might help to develop the exhibition and PAX's over-all cooperation with the PMC. A first issue is related to the missing voices of the Bosnian Serbs in the exhibition. In an ideal situation, an exhibition regarding Srebrenica would incorporate all voices, the testimonies of victims, perpetrators, witnesses and the international community. The PMC, however, is first and foremost a place for (and owned by) the victims and survivors of the Srebrenica genocide. Under the given circumstances, in which denial of the Srebrenica genocide became the rule rather than the exception, there was and is no possibility to include the voices of the Bosnian Serbs in an exhibition. ${ }^{15}$ Nevertheless, the producers of the exhibition did take effort to avoid insulting expressions regarding the Bosnian Serbs. So, in the exhibition, the (Bosnian) Serbs are explicitly not indicated as četnik, the nationalistic movement with its roots in the Second World War which strives for a Greater Serbia, free from non-Serbian ethnicities (Cornelisse 2006, pp. 57, 121-126). It will be an effort - one that possibly takes many years - to find a common ground through dialogue and meetings of all affected communities before it will be possible to include the voices of the (Bosnian) Serb community in a new exhibition. Before reaching such a

15 Cf. the recently installed memorial plaque in Srebrenica town center by the organization Istocna Alternativa. The inscription on the plaque says it is "in memory of the innocently killed Serbs of the Podrinje and Birac area in the period 1992-1995, committed by Muslim hordes"' (sic!). 
level of inclusivity in any exhibition, following dialogue and meetings, first public statements, interviews, articles as well as documentaries and possible theatre plays and movies will have paved the way. At least, the search for common ground demands among others a clear distinction between perpetrators, sympathizers and witnesses of the crimes committed by the (Bosnian) Serbs and to get rid of stereotypes of collective guilt. ${ }^{16}$

Second, recognition of the sufferings by the victims is a key issue. Part of this recognition is realized by the exhibition itself. The exhibition as such is a recognition of what happened to the victims. It gives a full account of the war, the fall of the enclave, the deportation, the massacre and the mass graves, and the law suits. This offers the survivors a strong experience of being heard and seen. As Suhra Sinanovic, survivor herself and president of the Association Women of Podrinje, stated after the official opening of the exhibition, 9 February 2017: "We waited so long for such an exhibition. Nothing here in Srebrenica is more powerful than this museum. We, as survivors, needed this dearly. It is breath-taking. People from all over the world should come and see". In case it will be possible one day to incorporate the voices of Bosnian Serb citizens, preferably starting with the ones who did not take part in the war crimes, it will add to the recognition. At least this is stated by the psychoanalyst Vartan Volka: “... one's own side may raise monuments to memorialize its suffering (...) a victimized group needs to have its losses recognized by its opponents" (cited in Denich 1994, p. 378). At this very moment, this seems to be a "mission impossible", for the (Bosnian) Serbs still refuse to face their past. To mention just one example: since 2016, Srebrenica is led by a Serb mayor, who refuses to call the Srebrenica massacre a genocide (see Spaic 2017). The denial of genocide is increasing at this very moment.

\section{Conclusion}

In this article we have described the design and content of the Srebrenica exhibition and reflected on the consequences of the choices that had to be made to make the exhibition possible. We are very much aware that this exhibition is but one step in a much longer process of social reconstruction in Bosnia and Herzegovina and a new relationship with the Netherlands. The exhibition indeed constructs a shared sense of truth about the Srebrenica genocide, not in the form of one narrative or one truth, but as a physical and metaphoric space in which survivors, Dutchbat veterans and other visitors can endure the plurality of truths. The exhibition aims at telling the story of the genocide, while providing people the opportunity to reflect on what happened from various perspectives. It does not hide the failures of the international community and Dutch politicians, nor does it conceal the failures of Dutchbat. In their first responses to the exhibition, both the women of Srebrenica and the Dutchbat veterans stressed the importance of acknowledgment of what happened in July 1995. This acknowledgment and the confrontation with the multiple narratives might stimulate the intra-group

\footnotetext{
${ }^{16}$ This is also what the ICTY had to explain over and over again. It is focusing on individual responsibility of war criminals, it is not about collective guilt of ethnic communities. Still, there are the dynamics of a collective, nationalistic milieu in which radical leaders could mobilize large parts of the communities to support their nationalistic claims. For a full understanding of the recent Balkan wars these societal processes can and should not be ignored. See for the nationalistic movement in Serbia, the role of the Serbian Orthodox Church and Slobodan Milosevic (Perica 2002, especially chapter 8).
} 
dialogues as a precondition for inter-group dialogues. Our reflections on the concepts of "various voices" and "plural truths" should be read as part of this ongoing process.

\section{References}

Alphen, E.v., 1997. Caught by History: Holocaust Effects in Contemporary Art, Literature, and Theory. Redwood City: Stanford University Press.

Attila Hoare, M., 2010. Bosnia-Hercegovina and International Justice. East European Politics and Societies [online], 24(2), 191-205. Available from: https://doi.org/10.1177/0888325409356462 [Accessed 3 October 2018].

Bellamy, D., (with Reuters), 2018. Serbian peace group marks Srebrenica anniversary in Belgrade. Euronews [online], 11 July. Available from: https://www.euronews.com/2018/07/11/serbian-peace-group-marks-srebrenicaanniversary-in-belgrade [Accessed 3 October 2018].

Bergholz, M., 2018. Violence as a Generative Force: Identity, Nationalism, and Memory in a Balkan Community [online]. Ithaca: Cornell University Press. Available from: https://doi.org/10.7591/9781501705885 [Accessed 3 October 2018].

Blom, J.C.H., and Romijn, P., 2002. Srebrenica, een "veilig" gebied: Reconstructie, achtergronden, gevolgen en analyses van de val van een Safe Area. Amsterdam: Boom.

Brosius, C., 2007. The unwanted offering: Ubiquity and success of failure in a ritual of the Hindu right [online]. In: U. Husken, ed., When Rituals Go Wrong: Mistakes, Failure, and the Dynamics of Ritual. Leiden/Boston: Brill, 296-324. Available from: https://doi.org/10.1163/ej.9789004158115.i-377.103 [Accessed 3 October 2018].

Cornelisse, E., 2006. Verdeeld verleden: De constructie van sociale herinneringen van Bosnische Moslims en Bosnische Serviers in naoorlogs Srebrenica. M.A. Thesis. University of Amsterdam.

Denich, B., 1994. Dismembering Yugoslavia: nationalist ideologies and the symbolic revival of genocide. American Ethnologist [online], 21(2), 367-390. Available from: https://doi.org/10.1525/ae.1994.21.2.02a00080 [Accessed 3 October 2018].

Faber, M.J., 2002. Srebrenica: De genocide die niet werd voorkomen. Utrecht: IKV.

Gallagher, T., 2003. The Balkans after the Cold War: From Tyranny to Tragedy [online]. London: Routledge. Available from: https://doi.org/10.4324/9780203398180 [Accessed 3 October 2018].

Grebo, L., 2018. Bosniak Ex-Fighters Convicted over 1992 Srebrenica Murders. BalkanInsight [online], 14 September. Available from: https://balkaninsight.com/2018/09/14/bosniak-ex-fighters-convicted-over-1992srebrenica-murders-09-14-2018/ [Accessed 29 November 2018].

Heynders, O., 2014. Speaking the Self, Narratives on Srebrenica. European Journal of Life Writing [online], vol. 3, 1-22. Available from: https://doi.org/10.5463/ejlw.3.43 [Accessed 3 October 2018].

Hoondert, M., 2018. Srebrenica. Conflict and ritual complexities. In: M. Hoondert, P. Mutsaers, and W. Arfman, eds., Cultural Practices of Victimhood [online]. 
London/New York: Routledge, 19-38. Available from:

https://doi.org/10.4324/9781315148335 [Accessed 3 October 2018].

Humphrey, M., 2012. Victims, civil society and transitional justice in Bosnia and Herzegovina. Temida [online], 15(1), 59-75. Available from:

https://doi.org/10.2298/TEM1201059H [Accessed 3 October 2018].

International Committee of the Red Cross, 1997. Missing Persons on the Territory of Bosnia and Herzegovina. $3^{\text {rd }}$ ed. Geneva: ICRC.

International Criminal Tribunal for the former Yugoslavia, 2008. Appeals Chamber Acquits Naser Orić [online]. Press release. The Hague: ICTY, 3 July. Available from: https://www.icty.org/en/press/appeals-chamber-acquits-naser-ori\%C4\%87 [Accessed 29 November 2018].

Jones, N.A., Parmentier, S., and Weitekamp, E.G.M., 2014. Transitional Justice in Bosnia-Herzegovina: Understanding Accountability, Reparations and Justice for Victims. In: J.A.M. Wemmers, ed., Reparation for Victims of Crimes Against Humanity: The Healing Role of Reparation [online]. London/New York: Routledge, ch. 9. Available from: https://doi.org/10.4324/9781315881867 [Accessed 18 November 2019].

MacDonald, D.B., 2003. Balkan Holocausts? Serbian and Croatian victim centred propaganda and the war in Yugoslavia [online]. Manchester University Press. Available from: https://doi.org/10.7228/manchester/9780719064661.001.0001 [Accessed 3 October 2018].

Meyer, E., 2010. Memory and Politics. In: A. Erll and A. Nunning, eds., A Companion to Cultural Memory Studies. Berlin/New York: De Gruyter, pp. 173-180.

N1 Sarajevo, 2018. Bosnian Serbs commemorate 1992 Zalazje killing. N1 [online], 12 July. Available from: http://rs.n1info.com/English/NEWS/a403566/Local-Serbsmark-anniversary-of-killing-in-Bosnia.html [Accessed 28 November 2018].

Nettelfield, L.J., and Wagner, S., 2015. Srebrenica in the Aftermath of Genocide. Cambridge University Press.

Nils, C., 2005. Restorative and retributive justice in the context of war and war crimes. Temida, 8(4), 27-32. Available from: https://doi.org/10.2298/TEM0504027N [Accessed 3 October 2018].

Nora, P., 2001. Rethinking France=Les lieux de mémoire. Trans.: M.S. Trouille. University of Chicago Press.

PAX, 2014. Dutch contribution to the second phase of the Potočari Memorial Centre. Project proposal. April. Utrecht: PAX.

PAX, 2017. Dutch Contribution to the second phase of the Potočari Memorial Centre (June 2014-February 2017). Report. Utrecht: PAX.

Perica, V., 2002. Balkan Idols: Religion and Nationalism in Yugoslav States [online]. Oxford University Press. Available from: https://doi.org/10.1093/0195148568.001.0001 [Accessed 3 October 2018]. 
Pollack, CE., 2003. Intentions of burial: Mourning, politics, and memorials following the massacre at Srebrenica. Death Studies, 27(2), 125-142.

Reijnders, S., 2013. Places of the Imagination: Media, Tourism, Culture. Farnham: Ashgate.

Remijnse, S., and Baanders, I., 2018. Negotiating Narratives - the Case of Srebrenica [not yet published].

Sachs, A., 2000. The Soft Vengeance of a Freedom Fighter. Berkeley: University of California Press.

Shaheed, F., 2014. Memorialization processes: Report of the Special Rapporteur in the field of cultural rights (A/HRC/25/49) [online]. United Nations General Assembly, Human Rights Council, 25th session. 23 January. Available from:

https://www.ohchr.org/EN/HRBodies/HRC/RegularSessions/Session25/Documen ts/A HRC 2549 ENG.DOC [Accessed 18 November 2019].

Simic, O., ed., 2017. An Introduction to Transitional Justice [online]. London/New York: Routledge. Available from: https://doi.org/10.4324/9781315672649 [Accessed 18 November 2019].

Spaic, I., 2017. Srebrenica's Serb Mayor Repeats Denial of Genocide. BalkanInsight [online], 13 April. Available from:

https://balkaninsight.com/2017/04/13/srebrenica-s-serb-mayor-repeats-denial-ofgenocide-04-13-2017/ [Accessed 5 October 2018].

Spijkers, O., 2016. Questions of legal responsibility for Srebrenica before the Dutch courts. Journal of International Criminal Justice [online], 14(4), 819-843. Available from: https://doi.org/10.1093/jicj/mqw043 [Accessed 18 November 2019].

van den Berg, D., 2014. Rekindling a National Debate. How Public and Private Recognition can shift the Dutch Discourse on Srebrenica. In: L. van Liere and K. Spronk, eds., Images of Enmity and Hope: The Transformative Power of Religions in Conflicts. Zurich/Berlin: LIT, 105-144.

Winter, J., 2010. Sites of Memory and the Shadow of War. In: A. Erll and A. Nunning, eds., A Companion to Cultural Memory Studies. Berlin/New York: De Gruyter, 6174.

\section{Case law}

International Criminal Tribunal for the former Yugoslavia, n.d. Orić (IT-03-68) [Case Information Sheet] (online). Available from: https://www.icty.org/case/oric/4 [Accessed 28 November 2018].

Uitspraak Hoge Raad, 06-09-2013, Zaaknummer 12/03324 (ECLI:NL:HR:2013:BZ9225) [online]. Available from:

https://uitspraken.rechtspraak.nl/inziendocument?id=ECLI:NL:HR:2013:BZ9225 [Accessed 3 October 2018].

Uitspraak Hoge Raad, 19-07-2019, Zaaknummer 17/04567 (ECLI:NL:HR:2019:1223) [online]. Available from:

https://uitspraken.rechtspraak.nl/inziendocument?id=ECLI:NL:HR:2019:1223 [Accessed 3 October 2018]. 